\title{
Research on the Establishment of Judicial Organization for Protection of the Rights of Nations
}

\author{
Mohsen Ghasemi \\ Law, Moscow State University, Unit 4, No. 68, Hayamanesh Lane, Dabestan St., Pol-e-Sed Khandan, Tehran, Iran \\ Email: ghaem_powerplant@yahoo.com
}

\section{Doi:10.5901/mjss.2015.v6n6s6p164}

\section{Abstract}

\begin{abstract}
Of late the humanization of international law has considerably undermined states' sovereignty. This trend has gained a momentum in the recent years and has rendered International law closer to be nation-centered more than ever. On the other hand, establishment and expansion of the jurisdiction assigned to handle human rights violations as well as an anticipation of the extent of implementation of the judicial body have been positive steps to promote human rights. Furthermore, they have prevented the violators' evading justice. As well, this trend reinforces the possibility of seeking justice for the victims of these violations. Establishment of an international judicial organization for protection of the rights of nations along with transnational and regional independent judicial bodies are the means that pave the path to seek justice against violent acts of state agents. This mechanism would enhance support for citizenry vis-à-vis state sovereignty. The researcher would address these goals as follows: - Articulation of the theoretical foundations and the necessity of a judicial organization for protection of the rights of nations. - Configuration of the framework of such judicial organization for protection of the rights of nations. - Explaining the functions of the judicial organization for protection of the rights of nations for achieving the above goals, descriptive-analytical method has been employed.
\end{abstract}

Keywords: Establishment of Judicial, Organization, Protection, Rights of Nations.

\section{Introduction}

After a perusal in international documents it is clear that one of the goals of the United Nations is to disseminate, promote and respect human rights and fundamental freedoms for all regardless of race, gender, language and religion. These rights have coexisted along with human existence and every human being is entitled to them. Human rights are inalienable and no one can be deprived of them due to political, economic and social reasons. Hence, no individual or group enjoys priority in terms of these rights, nor can a group could marginalize on grounds of race and ethnicity.

The Charter of the United Nations commits all members, due to the urgency of the provision of stability and welfare for all nations, to undertake full cooperation on an individual or collective basis based on the establishment of fundamental freedoms predicated on equal rights and sovereignty for all regardless of race, ethnicity, gender, language or religion. Ergo the establishment of the Human Rights Tribunal is a novel concept in line with cooperation with the United Nations to promote quality of life, human rights, and security.

\section{Argument}

Sovereignty is a concept that dates back to the era of tribal societies in antiquity. There have always been an individual or a group who claimed superiority over other members of the tribe and in order to rule over others confronted other contenders that sometimes led to its own demise. Even though this concept over the course of history has undergone changes, the main idea germane to it, i.e. domination, has remained intact. There have only been superficial changes to the effect that when the mightiest individual seized chieftaincy of the tribe, in some primitive societies the elderly and in some the most powerful person assumed power. In the middle Ages, the pope considered himself as a heavenly ruler and God's deputy on earth; the kings viewed themselves as terrestrial rulers and the peoples' representatives. After Westphalia peace treaties signed in Münster and Osnabrück in 1648, a new concept of sovereignty appeared in European societies that put an end to Papacy and Empires, and ushered a new era in the history of European nations. Now the notion of sovereignty was positioned next to that of state, and the ideation of state sovereignty emerged.

State sovereignty has undergone many changes in the course of history. Even though inking the Westphalia treaties led to the birth of the concepts such as state and a respectful recognition of other sovereign states, until the 
passage of the United Nations charter in 1945 these concepts could not be implemented and were often breached by other states; the outbreak of the two world wars are a testimony to this claim.

The humanization of international law in the recent years has largely diminished the abrogation of state sovereignty. Of late this trend has gained a wonderful momentum that has led to the people-oriented tendency in international law. On the other hand, the establishment and promotion of the legal and quasi-legal tribunals to engage with human rights violations as well as decisions towards further implementation is a positive move to promote human rights. Furthermore, it has prevented that the violations remain unpunished (the international tribunal was established to address lawlessness). As well, it reinforces the chances to mete out justice with regard to victims' rights.

One of the means that paved the way to seek justice against the unlawful acts of state actors is to establish transnational and regional judicial and quasi-judicial authorities that would function without being required to enjoy diplomatic support from the government in question. In the light of the recent developments and the increasing efforts by the International Law Commission and other related bodies this prerequisite would not provide a working solution, it actually made it more difficult to reach. The reason being that the government in question would argue that the matter lies within its own jurisdiction; hence, the government has the prerogative to support its citizen or not. Many times the government refused to extend support, therefore the citizen's right is not looked after. In view of the inadequacy of this approach, another solution must be sought.

Today it can no longer be argued that the geographical extent of human rights of the governments committed to human rights is solely limited to the jurisdiction within their borders. Given the judicial procedures of the judicial and quasi-judicial systems and the interpretations in place, and based on the content of the legal instruments that create liability, the member governments of the Convention would be responsible in principle wherever they apply their jurisdiction proportionate to their legal authority. Indeed, the organizations observing the implementation of human rights laws strive to further support the matter through the expansion of the jurisdiction of these rights. Accordingly, every single individual would be protected, and they would provide the means to seek justice if their rights are trampled. Hence, the geographical scope of the states' commitments to human rights is constantly evolving.

States, regardless of their liabilities within their borders, are responsible towards their representatives, agents, and even administrative staff behavior should they breach any legal convention. The mode of applying jurisdiction is an exception to the state jurisdiction in its territory carried out through the related bodies. This situation would be analogous to the military actions of a member state whose forces in another jurisdiction -normally the Convention was not recognized in that specific territory- which would lead to human rights and freedoms violations specified in the Convention.

"Human rights are a manifestation of human dignity, and the states' obligation to observe them originates from this dignity already pronounced in the United Nations charter and the human rights declaration". Whether human rights are intertwined with human dignity, and human rights have aligned with this dignity, it seems that the onus is all states concerned to observe these rights based on a guiding principle of international law.

Regardless of any contractual obligation, depriving humans from freedom and inflicting physical pain are clearly contrary to the goals in the charter of human rights. Furthermore, postponing such obligation to any considerations is a contravention of the spirit of the United Nations Organization and the international community. Therefore, it appears that one of the most important means to guarantee human rights is to expand the geographical scope of the states' obligations.

The goal and mission of a convention such as the European Human Rights Convention is to maintain the "general European Order" to protect humans. As well, the European Human Rights Court regards the European convention as having a special feature, a law-making document that guarantees general order in Europe to protect human rights. It pinpoints that the role of this Convention is to guarantee supervision over fulfillment of the obligations of the parties member to the Convention.

In the first glance, the European Convention reminds the reader of its regional ethos. On the other hand, however, the European Court of Human Rights, through a number of decisions, sees its regional jurisdiction in contrast to article 19 of the Convention, the article that allows no territorial restriction on the existing system in this convention. In several decisions of the European Court of Human Rights (either by counsel representing either party or by Judges) it has been accentuated that imposing geographical limits to the jurisdiction of the European Convention would inflict "an irreparable damage on the protective aspect of the European Human Rights Convention". Hence, it appears that in terms of geographical scope human rights rules follow specific regimes that other international law principles do not have access to.

The specific foundation of human rights treaties and other conventions containing anthropo-centric themes have led to a system different from international principles, tailored to their specific nature. For instance, with regard to applying 
justice, a separate system has been dictated to governments "in such a way that applying the right to protect human rights conventions is at times seen as contrary to the goal of the convention. Even some experts would argue that due to their unique themes human rights conventions cannot be protected; hence, such a declaration on these treaties has no effect (not the declaration on protection) to the point that member states are not even obligated to protest it".

Also, from the perspective of the European Court of Human Rights, the judicial authority to handle human rights issues, in order to gain legitimacy and recognition, should consider international law. Also, the tribunal should consider a state's responsibility to conform to international law, although it should consider also the different and specific nature of a human rights treaty while viewing a binding human rights document".

The Charter of the United Nations should be seen as the prototypical document to determine the states' obligation to honor the geographical scope in the context of human rights. Para. 7 of Article 2 of the Charter of the United Nations refers to "domestic jurisdiction of States". It seems that this section should be viewed as the foundation for the evolutionary trajectory of the concept in question. State jurisdiction is predicted on promoting international law and relations. Hence, issues pertaining to international law in general should not be necessarily considered within state jurisdiction. However, the existing international law in international treaties has placed the specific topic stipulated in these treaties beyond any exclusive jurisdiction. Even the international law created due to mutual relations has also positioned its goal beyond any state jurisdiction.

On the other hand, the position of human rights in the charter of the United Nations has been specified through terms such as "promotion", "encouragement", and "protection". The terms "promotion" and "encouragement" towards observing human rights are part and parcel of the charter; hence, all measures regarding them are no longer within the exclusive domain of the states. However, with regard to "protection" this authorization has been stipulated differently, and the difference emanates from the definition of this concept. Therefore, all measures related to it should be divided into direct and indirect measures. The direct measures to protect human rights (such as litigation regarding human rights violations, responsibility, decisions regarding the quantum and mode of compensation, international execution of the decision, etc) are within the states' internal domain, while instances of systematic violation of human rights, genocide, negligence on discrimination, or self-determination all fall within the purview of the United Nations. It should be said that some experts speak of concurrent jurisdiction.

At this point reference should be made to the four Geneva conventions. According to many international jurists, the human rights declaration is not the first binding human rights text. Article 3 is repeated in four conventions due to the long history of the human rights. At the time of conflict parts of it have focused on peace time. This matter itself triggered the new global approach to human rights. The rights stipulated in this article are in fact the same rights mentioned in the human rights declaration and the International Covenant on Civil and Political Rights adopted by the United Nations General Assembly in 1966. Obviously, they are part of imperative rules of international law. This reality points us to the fact that in order to trace the genesis of human rights ideas one could refer to the documents that by nature are within the framework of humanitarian law.

Article 1 of all four conventions requires all member states to commit themselves "to follow the convention under any circumstances and warrant its implementation". The term "under any circumstances" implies that spatially and temporally there is no limitation to implement the convention in question and member states are bound to observe it. Also, this article states "warrant its implementation". In other words, the member states are bound to implement the conventions and demand their subjects to follow them as well. Therefore, given the existence of elements of human rights in these conventions, one can conclude that the obligations of the member states in the implementation of the human rights components of the conventions beyond their jurisdiction can be expanded in such a way that it could cover those subjects who reside abroad.

Some traces of this concept could also be seen in the civil and political pact and the annexed protocol. Para. 1 of article 2 of the International Covenant on Civil and Political Rights stipulates that "Each state party to the present Covenant undertakes to respect and to ensure to all individuals within its territory and subject to its jurisdiction the rights recognized in the present Covenant"

\section{Human Rights Institutions}

\subsection{General Assembly}

According to article 13 of the charter, one of the duties of the General Assembly is promoting international cooperation in the economic, social, cultural, educational, and health fields, and assisting in the realization of human rights and fundamental freedoms for all without distinction as to race, sex, language, or religion". Per articles 14 and 15 of the 
Charter, the General Assembly can make recommendations on human rights, examine the reports of other UN organs and, if necessary, establish sub-committees. By the same token, the General Assembly has presented recommendations, drafted and legislated international conventions, established sub-committees, and has issued several human rights resolutions. The existing consensus on human rights in the UN General Assembly has played a great role after the end of cold war and has facilitated promotion of the fundamental principles of human rights in the international community. This organ, through the expanded interpretation of its duties and condemnation of human rights violations, has impacted national sovereignty.

\subsection{Security Council}

The UN Security Council, too, engages with human rights issues. For instance, the Security Council recognized human rights violations, the apartheid policy of the South African government, and the situation in Namibia and South Rhodesia. In addition to the fact that Security Council carries political weight across the globe, based on article 25 of the Charter of the United Nations that obligates members to accept and implement Security Council resolutions. Through adopting appropriate measures it can also make significant contributions to promote human rights and push towards its implementation within national borders of states. On April 14, 1992 the power of the Security Council was confirmed by the International Court of Justice through the Court's comment to the effect that states' obligations with regard to the Charter of the UN take priority over other obligations. Chapter 7 of the Charter of the United Nations, as a foundation of the legitimacy of the Security Council measures, even though bears no relation to human rights, yet the Security Council, based on article 39 of the Charter, can discern whether human rights violations in any society can jeopardize peace and international security. After the end of cold war, there were efforts so that the Security Council assumes greater responsibility to secure peace and international security. Accordingly, following human rights violations in El Salvador the Security Council resolved to dispatch observing delegations there to safeguard human rights agreements. Also, the Council observed the elections in Angola, Namibia, and Cambodia. Besides, Aristide, the first democratically-elected president of Haiti, was restored to power by the Security Council.

\subsection{International Court of Justice}

Since its inception, the International Court of Justice has handled several human rights cases. The examples are:

- The Barcelona Traction Case (Judgment of February 5, 1970), declaring international support for basic human rights.

- The case of Hostage Crisis of the American Consular and Diplomatic Staff in Tehran (Judgment of May 24, 1980)

- The case concerning Elettronica Sicula S.p.A (Judgment of July 20, 1989), defining what is deemed as autocratic action.

\subsection{The Secretariat}

The secretary general, as the authority in charge of all activities in the UN, plays a great role in focusing on human rights. The secretary general makes his/her best efforts to promote human rights and support for it on a global level. As well, he/she plays a vital role to draw the attention of the Security Council, the general assembly and other organs in the United Nations towards human rights, peace and security in certain parts of the world. Since the end of cold war the efforts of the secretary general have been on the rise.

\subsection{Office of High Commissioner for Human Rights}

Upon the recommendations of the 1993 Human Rights Conference in Vienna regarding the establishment of the post of high commissioner for human rights, in 1994 the General Assembly reached a consensus in this regard. According to the resolution adopted, the UN high Commissioner for human rights, acting as the deputy Secretary-General, would be in charge of the UN activities with regard to human rights. The human rights Centre is also in charge of administrative work of the organization. It would function under High Commissioner foe Human Rights. 


\subsection{Specialized Agencies of the United Nations}

Among specialized agencies of the UN, International Labor Organization, UNESCO, Food and Agriculture Organization, and the World Health Organization pay special attention to human rights.

The International Labor Organization has passed important resolutions on basic rights of workers, and work conditions. According to article 26 of the constitution of the International Labor Organization, any state can lodge a complaint against another state, and also according to article 24 , any labor organization or employer can lodge a complaint against any government with regard to labor rights violations.

The United Nations Educational, Scientific and Cultural Organization (UNESCO) plays a vital role in the global institutionalization of the human rights, science, culture, and communication. The executive committee of UNESCO in 1978 has provided opportunities for the victims of human rights violations in terms of education, science, culture, and communications, to lodge complaints to this organization.

The Food and Agriculture Organization (FAO) per its constitution is obligated "contributing toward an expanding world economy and relief from hunger". It also is concerned "to strike a balance between food supply and world population".

The World Health Organization (WHO) has also stipulated in its constitution that "The enjoyment of the highest attainable standard of health is one of the fundamental rights of every human being. Governments have a responsibility for the health of their peoples which can be fulfilled only by the provision of adequate health and social measures".

Specialized organizations, through recommendations or demands, ask member states to observe human rights.

Human rights advocacy organizations are not functional without proper supervision mechanisms with regard to complaints and grievances. The goal is to mete out justice with regard to the victims' complaints. It can be achieved only through a sound supervision protocol. For instance, along with the responsibility of the member states of the European Convention of Human Rights to abide by the decisions of the European tribunal, Para. 2 of article 46 holds the ministerial committee of the European Council to supervise the implementation of these decisions by the states.

\subsection{Information Regarding the Project}

Argument: (definition of the concept, ambiguities, variables, and research goal)

Given the development of the regional and international institutions and their activities we are led to believe that support for humans in these bodies has further flourished. Their articulation of human dignity and also legislations regarding human rights have reached a point that, in view of some experts, we see an oversupply of laws. These efforts of the international community, since its inception, created an ambience where all parties to international law, governments, organizations, and individuals would become cognizant of the importance of the matter. Yet the increasing trend in passage of the laws did not help a consolidation of the rights of individuals. As explained before, international community started to establish organizations towards the realization of these goals so that human rights would be protected more than ever. The organizations established within the framework of the United Nations are considered a positive step forward and they have played a strategic role in the development of a legal system regarding human rights. However, the established organizations have been always heavily impacted by state sovereignty, and the states' political meddling has undermined nations' rights. A deeper examination of state sovereignty would betray the fact that normally peoples' rights are trampled as this sovereign state that claims to create order for the nations economic, political, and social life, is tyrannical by nature. This unruly nature should be checked by a higher power. The United Nations is a body that has largely pushed states through the existing mechanisms and popular opinion to observe human rights. Despite these efforts and the mechanism in place, state sovereignty is the dominant factor and within these states humans are oppressed by the sovereign state.

Peace and international security are lofty goals for the international community, and for the realization of this goal numerous efforts have been undertaken. States have been instrumental in this regard. Given the state-oriented nature of the international community, this goal cannot see full fruition. The tendency in international law to a nation-centered approach and a transformation of the state-oriented international law in recent years are witness to this claim.

All existing human rights organizations in the UN that support human rights are quasi-judicial or lack legal apparatus. There is no organization judicial by nature that could lodge a complaint against the aggressor state. There are parallel organizations in the UN, yet there is nothing beyond this point. Hence, the humanization of the international law and threats against human security necessitate the establishment of a judicial organization in the UN that is objective so that all nations that are not able, for any reason, to attain justice within their own national legal systems, would be able to bring an action through a comprehensive system under supervision of the United Nations. Hence, the observation of 
human rights would increase and all states would endeavor to improve their legal systems. This approach requires the establishment of a judicial organization for protection of the rights of nations. This organization should be created so that the demands of the nations as stated in the preamble of the Charter of the United Nations are met. The new structure of this organization will be designed based on parallel models so that those who cannot seek justice within their national borders would seek help from this organization. The Judicial Organization for Protection of the Rights of Nations would enable individuals to lodge a complaint against the aggressor state. This organization would recruit judges of highest level of expertise and integrity, and through international law would hear the cases. If found guilty, the aggressor state would be convicted. The implementation of the decision made by the Judicial Organization for Protection of the Rights of Nations would require cooperation of the Security Council, human right organizations, regional institutions such as NATO, and third party states.

Should the aggressor state wish to appeal the decision, this tribunal would allow it to do so, this is the ultimate calling of this organization. The Judicial Organization for Protection of the Rights of Nations, like any other newlyestablished organization, would require feasibility studies. In this regard the academic foundations of this organization will be fully explained.

\section{Research Goals}

The research goal is to delineate the legal structure of this judicial organization and an effort to accentuate the importance of establishing this organization so that human rights within the sovereignty of the states would be protected.

\subsection{The Significance of the research}

Given the commitment of the states to the Charter of the United Nations to promote respect for human rights and fundamental freedoms; in view of the Universal Declaration of Human Rights and the International Covenant on Economic, Social and Cultural Rights; and based other international protocols and documents related to human and humanitarian rights and international criminal law; in the face of threats to human security at present there is an urgent need for establishment of a judicial organization for protection of the rights of nations.

\section{The Research Questions and Hypotheses Questions:}

Once certain conditions are met as well as an expansion of state jurisdiction, is it possible to establish an institution as judicial organization for protection of the rights of nations to compel states to observe human rights?

Given the overall expansion of international bodies, what is the compelling reason to establish a judicial organization for protection of the rights of nations?

What would be the mechanisms of Judicial Organization for Protection of the Rights of Nations to safeguard human rights as much as possible?

\section{Research Hypotheses}

The entire international documents that to date have won the approval of followers of international law in the UN system advocate support humans as the only homo sapiens who could thrive in a reasonable legal space. Early studies indicate that even though the idea of establishing such as organization, like other international bodies, sounds idealistic, it would be able to safeguard human rights on a wider scale vis-à-vis state sovereignty; this would be the most significant legacy of the nation-centered international law in this century.

\section{Literature Review}

This proposal is quite fresh and innovative, having no antecedent.

\section{Definition of Key Terms}

- State: In this research, it is the centralized power in a country that wields sovereignty.

- Sovereignty: It means internal control and independence. First, it lay the kings, then states, and later the people. "Sovereignty in practice, especially with regard to the outer world has limitations; hence, there is no 
absolute power and freedom. Even the most powerful countries cannot plan their foreign policy without considering international realities. Clearly small states have less independent, and depend daily on major powers in terms of economy, politics, and military".

Treaty: Treaty is an agreement under international law entered into by two or more states, signed by their lawful representatives and endorsed by the heads of the states. Par. "a" of article 2, Part 1 of the 1969 Vienna Convention of the Law of Treaties, in line with the old models considers a treaty as a written commitment between states, and makes no mention of other advocates of international law. Nevertheless, in article 4 it implicitly mentions this reality and corroborates the validity of state treaties with other international law advocates, treaties reached between them, as well as verbal treaties. Broadly speaking, a treaty means a pact entered into by members of the international community to realize certain legal goals; therefore, a treaty can be likened to law and contract in internal law.

\section{Methodology of Research}

The research method used in this project is descriptive-analytical method, and library sources will be utilized as well.

\section{Research Structure}

With reference to the title of the research and given the questions mentioned above, the project is divided into 2 sections. The first part is on "the necessity of establishing the Judicial Organization for Protection of the Rights of Nations and the Characteristics of the Organization". In the second section, "The structure of Concept of the Judicial Organization for Protection of the Rights of Nations with the UN System" will be addressed.

Organizational Chart of the Judicial Organization for Protection of the Rights of Nations

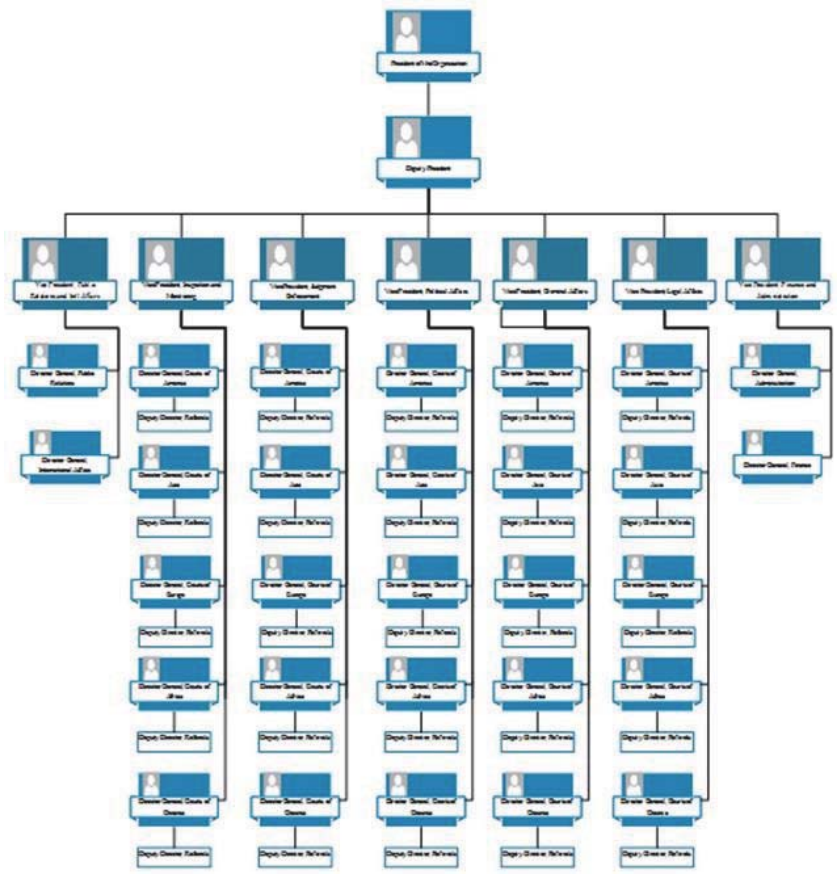

\section{Conclusion}

The nation-centered international law system has engendered an ambience so that states would pay special attention to citizens. States should treat their subjects within their borders in a fair manner and abide by international laws in the process of passing and enacting their own laws. They should view people as pivotal in their legislation. This approach 
would necessitate establishment of an institution such as judicial organization for protection of the rights of nations so that this organization, with the support of the UN member states, would better safeguard human rights internationally. In cases of violations, people may contact this judicial organization for protection of the rights of the nations and seek justice. This approach then would require all states' support and also the will of international organizations to safeguard the citizens' full rights on a global scale.

Although citizens of every country have responsibilities towards their state, such responsibilities have nothing to do with human rights. Human rights are the rights and freedoms that the state owes to the people. It should be acknowledged that the traditional notion of sovereignty has lost its validity due to the changes in international law. Since a majority of states have passed or joined human rights treaties, it could be said that human rights enjoy universality.

\section{References}

Aghaee, Seyd Davoud, The Role of Security Council in the New World Order, Peyk -Farhanf press, Tehran, 1996.

Falsafi, Hedayuttal, Human Rights in Contemporary International Law, Majelleh Tahqiqat Hoghooghi, Shaeed Beheshti University Press, No, 18, Summer-Winter 1996, Tehran.

Sharifi, Taraz Toohi, Hossein, Citizenship Rights: The Context and Impact, Mizan Legal Foundation, Tehran, 2014.

Shayegan, Farideh et al, Reinforcing International Cooperation for Human Rights, Tehran University Press, Tehran, 2011.

Mehrpour, Hossein, International Huam Rights, Ettelaat Publishing Press, Tehran, 2012.

Mir Abbassi, Seyd Bagher, The International Support System for Human Rights, Javdaneh Jangal Press, Tehran, 2013.

Molayee, Ayat, Human Rights and National Sovereignty, Ettelaat Siasi-va-Eqtesadi, No. 155-156, August-September 2000.

Zakerian, Mehdi, Human Rights in the New Millennium, Tehran University Press, 2011.

Tomuschat, Christian, translated by Hossein Sharifi Taraz Toohi, Human Rights, Mizan Legal Foundation, Tehran, 2104.

The website of: www.unhcr.org and www.un.org

Abedi G, Azimehr L, Rostami F, Mohammadi S. Applying a Model of Patient's Right in the State Hospital, Sari, Iran. (2012), International Journal of Collaborative Research on Internal Medicine \& Public Health. 2012; 4(2):103-110. 